Volume 4 Nomor 2 Oktober 2020

e-ISSN: 2549-9114 dan p-ISSN: 2549-9203

(Received: Juni-2020; Reviewed: Juli-2020; Published: Oktober-2020)

https://doi.org/10.26858/pembelajar.v4i2.14291

\title{
Hubungan Sosial Kognitif dan Life Skills Education Terhadap Kemampuan Adaptasi Calon Guru Pada Era Revolusi Industri 4.0 Mahasiswa S1 PTE Jurusan Teknik Elektro Universitas Negeri Malang
}

\author{
Artina Tri Wistiawatia, Setiadi Cahyono Putro ${ }^{a}$, Wahyu Sakti Gunawan Irianto ${ }^{b}$ \\ aUniversitas Negeri Malang \\ ${ }^{\mathrm{b} U n i v e r s i t a s ~ N e g e r i ~ M a l a n g ~}$
}

Corresponding e-mail: $\underline{\text { artinawistiawati@gmail.com, cahyono@gmail.com, gunawan@gmail.com }}$

Abstrak: Era revolusi industri 4.0 menuntut calon guru untuk dapat beradaptasi dengan baik (Y) karena terjadinya arus perubahan jaman terutama untuk calon guru SMK. Oleh sebab itu Mahasiswa sebagai calon guru harus memiliki Life Skills Education (X2) dalam pelatihan softskill maupun hardskill. Selain itu dalam beradaptasi calon guru (Y) diperlukan kemampupan berbaur dengan orang lain atau sosial kognitif (X1) sehingga adaptasi dapat dilakukan dengan baik. Penelitian ini bertujuan untuk mengetahui : (1) Deskripsi X1, X2, Y, (2) Hubungan X1 dengan Y, (3) Hubungan X2 dengan Y, (4) Hubungan X1 dan X2 dengan Y. Metode penelitian yang digunakan yaitu kuantitatif dengan rancangan penelitian deskriptif korelasional. Sampel penelitian sebanyak 84 siswa yang ditentukan dengan berpedoman pada teknik sampel jenuh. Variabel X1, X2 dan Y memiliki tingkat reliabilitas secara berurutan adalah 0.973, 0.985,dan 0.985. Secara Berurutan Nilai Sumbangan Efektif pada X1 dan X2 adalah 19.68\% dan 50.05\%. Secara Berurutan Nilai Sumbangan Relatif pada X1 dan X2 adalah $28.20 \%$ dan $71.80 \%$. Kesimpulan hasil yang diperoleh dari penelitian ini yaitu (1) X1,X2, dan Y dalam kategori sedang; (2) terdapat hubungan positif dan signifikan antara X1 dan Y, X2 dan Y, dan X1 dan $\mathrm{X} 2$ secara simultan dengan $\mathrm{Y}$.

Kata Kunci: Sosial Kognitif, Life Skills Education, Kemampuan Adaptasi pada Era Revolusi Industri 4.0

Abstract: The era of the industrial revolution 4.0 requires prospective teachers to be able to adapt well $(\mathrm{Y})$ because of the current changing times, especially for vocational teacher candidates. Therefore students as prospective teachers must have Life Skills Education (X2) in soft skills and hard skills training. In addition, in adapting prospective teachers (Y), it is necessary to be able to blend in with other people or social cognitive (X1) so that adaptation can be done. This study aims to determine: (1) Description of X1, X2, Y, (2) Relationship of X1 with Y, (3) Relationship of X2 with Y, (4) Relationship of X1 and $\mathrm{X} 2$ with $\mathrm{Y}$. The research method used is quantitative with design correlational descriptive research. The research sample of 84 students was determined saturated technique. Variables X1, X2 and $\mathrm{Y}$ have a level of reliability in sequence is $0.973,0.985$, and 0.985 . Sequentially Effective Contribution Value at X1 and X2 is $19.68 \%$ and $50.05 \%$. Sequentially the Relative Contribution Value at $\mathrm{X} 1$ and $\mathrm{X} 2$ is $28.20 \%$ and $71.80 \%$. The conclusions of the results obtained from this study are (1) $\mathrm{X} 1, \mathrm{X} 2$, and $\mathrm{Y}$ in the very medium category; (2) there is a positive and significant relationship between $\mathrm{X} 1$ and $\mathrm{Y}, \mathrm{X} 2$ and $\mathrm{Y}$, and $\mathrm{X} 1$ and $\mathrm{X} 2$ simultaneously with $\mathrm{Y}$.

Keyword: Cognitive Social, Life Skills Education, Adaptability of 4th Reolution of Industry

(O2020 -Ini adalah artikel dengan akses terbuka dibawah licenci CC BY-NC-4.0

(https://creativecommons.org/licenses/by-nc/4.0/) by penulis. 
Artina Tri Wistiawati, Setiadi Cahyono Putro, ahyu Sakti Gunawan Irianto. Hubungan Social Kognitif dan Life Skill Education Terhadap Kemampuan Adaptasi Calon Guru di Era Revolusi Industri 4.0

\section{PENDAHULUAN}

Menurut Listhari (2019) Industri 4.0 merupakan sebuah nama tren otomasi dan pertukaran data terkini dalam teknologi industri yang diperkenalkan di Jerman pada pameran industri Hannover Messe di Kota Hannover di tahun 2011. Revolusi Industri 4.0 mencangkup sistem siber-fisik, Internet $O f$ Thing (IOT) cloud computation, dan komputasi kognitif.

Revolusi industri 4.0 menjadi titik dimana seluruh aspek produksi di dalam industri menggunakan internet sebagai kontrol dalam manajemen industrinya. Proses produksi dalam industri pada era saat ini telah menggunakan sistem otomasisasi dimana seluruh proses baik pengolahan bahan baku dan quality control dioperasikan secara otomatis atau semi otomatis. Akibat dari perubahan proses dalam proses produksi menyebabkan manusia yang bekerja atau dalam kesiapan bekerja perlu meningkatkan kualitas diri dalam bekerja sehingga mampu bersaing dalam mendapatkan pekerjaan yang relevan sesuai dengan kemampuan.

Teknologi pada era industri 4.0 akan terus menerus berkembang, maka disisi lain harus didampingi dengan kemampuan berinovasi untuk menunjang agar perusahaan dapat terus berkembang menemukan ide-ide baru dan metode baru guna mampu menyesuaikan dengan perkembangan teknologi di era industri 4.0.

Sesuai dengan Undang-Undang Republik Indonesia (UU RI) No. 20 Tahun 2003 tentang Sistem Pendidikan Nasional, UU RI No. 14 Tahun 2005 tentang Guru dan Dosen, Peraturan Pemerintah No. 19 Tahun 2005 tentang Standar Nasional Pendidikan, maka Universitas Negeri Malang (UM) sebagai salah satuLembaga Pendidikan Tenaga Kependidikan (LPTK) bertugas untuk mempersiapkan lulusan mahasiswa calon guru yang mampu beradaptasi terhadap perkembangan yang terjadi di era revolusi industri 4.0.

Universitas Negeri Malang (UM) sedang mempersiapkan mahasiswa calon guru dengan standar pendidikan yang berkualitas, mandiri dan profesional. Mahasiswa calon guru diharapkan mampu menyesuaikan diri terhadap perkembangan teknologi utamanya yang digunakan untuk menunjang proses pembelajaran di era industri 4.0 maupun kehidupan di masyarakat. Berbagai upaya untuk mendukung pendidikan di era industri 4.0 dalam penerapan teknologi pada pembelajaran harus dilakukan. Kini perkembangan teknologi yang terjadi di beberapa aspek dapat dijalankan dengan IoT, otomatisasi dan digitalisasi.

Berdasarkan observasi terhadap mahasiswa S1 PTE Jurusan Teknik Elektro UM angkatan 2016 terdapat $61,9 \%$ mahasiswa calon guru masih memiliki kebiasaan untuk menunda pekerjaan atau tugas. Tetapi yang terjadi di era industri 4.0 untuk belajar hal-hal baru memerlukan waktu yang cepat. Jika memiliki kebiasaan untuk menunda pekerjaan maka akan mengalami ketertinggalan. Perkembangan teknologi di bidang pendidikan pada era industri 4.0 terjadi sangat cepat dan pesat, sehingga menuntut guru untuk selalu mengikuti perkembangan sehingga diperlukan sebuah penelitian untuk mengetahui hubungan sosial kognitif dan life skills education terhadap kemampuan adaptasi calon guru pada era revolusi industri 4.0 mahasiswa S1 PTE Jurusan Teknik Elektro Universitas Negeri Malang.

Tujuan dari diadakannya penelitian ini secara spesifi adalah : 1) mengetahuhui hubungan antara sosial kognitif dengan kemampuan adaptasi calon guru; 2) menethaui hubungan life skills education dengan kemampuan adaptasi calon guru; dan 3) mengetahui hubungan antara sosial kognitif dan life skills education dengan kemampuan adaptasi calon guru.

Adaptasi merupakan suatu proses penyesuaian diri terhadap lingkungan dan keadaan sekitar (Meinarno, 2011:66). Individu harus mampu melakukan interaksi yang positif terhadap individu lain di lingkungan baru. Adaptasi merupakan sebuah bentuk pembiasaan makhluk hidup untuk menyelaraskan diri terhadap rekan kerja ataupun lingkungan sekitar. Adaptasi dilakukan untuk memenuhi tuntutan situasi yang terjadi pada lingkungan tersebut. Adapun maksud dari adaptasi adalah suatu hal yang bersifat memaksakan diri untuk berperilaku, bersikap, dan membiasakan hal yang bukan kebiasaan asli dirinya

Berdasarkan pemaran diatas maka dapat disimpulkan bahwa kemampuan adaptasi calon guru dalam menghadapi era revolusi industri 4.0 adalah penyesuaian yang mau atau tidak harus dilakukan oleh guru dalam mempersiapkan era baru. Secara umum yang dimaksud revolusi industri adalah kemajuan yang terjadi pada aspek teknologi seiring dengan perubahan yang terjadi 
di bidang sosial, ekonomi, budaya maupun pola pikir masyarakat. Penyesuaian diri harus dilakukan oleh setiap individu untuk tetap mengikuti berbagai macam perubahan pada berbagai aspek kehidupan ataupun perkembangan teknologi di era industri 4.0.

Sosial kognitif merupakan teori belajar untuk berkembang dengan penggunaan yang sesuai pada lingkungan pendidikan dalam menghadapi era revolusi industri 4.0. Teori belajar sosial kognitif juga mempunyai peran besar dalam membentuk psikologi kepribadian seseorang. Melalui proses mental, sosial kognitif memberikan pengaruh terhadap perilaku yang sedang dikembangkan. Seperti contoh apabila individu guru mendapat banyak tekanan dan tuntutan untuk mempelajari banyak hal yang masih baru, terutama teknologi sebagai pendukung untuk menghadapi era industri 4.0. Maka dibutuhkan motivasi dan semangat jika guru mampu untuk mengikuti perkembangan era industri 4.0.

Wulan (2012:17) masih terkait dengan sosial kognitif, Lent mengembangkannya menjadi SCCT (Social Cognitive Career Theory). SCCT yaitu suatu konsep pengembangan karir atau transisi dari pendidikan ke bekerja. Dalam SCCT, transisi dari pendidikan menuju pencarian karir meliputi 6 proses, yaitu: (a) self efficacy dan outcome expectation; (b) pengembangan akademik dan minat karir; (c) pembentukan minat dan tujuan karir; (d) penjabaran tujuan ke dalam tindakan; (e) pengembangan akademik dan perbaikan kinerja; dan (f) dukungan sosial dan hambatan yang mempengaruhi pengembangan diri.

Berdasarkan pemaparan teori sosial kognitif di atas, indikator yang sesuai untuk mengukur permasalahan yang diangkat dalam penelitian sosial kognitif terhadap kemampuan adaptasi guru di era industri 4.0 yaitu: (1) mastery experience; (2) vicarious learning; (3) social persuasion; (4) affective state; (5) self regulation; (6) outcome expectation; dan (7) personal goals.

Life skills education atau pendidikan kecakapan hidup merupakan suatu persiapan dan pembekalan dasar kepada mahasiswa calon guru untuk menghadapi kendala di era industri 4.0. Melalui pembekalan kecakapan tersebut dapat digunakan mahasiswa calon guru untuk bertahan menghadapi tantangan di abad ke-21. Life skills education dapat memberikan manfaat kepada mahasiswa calon guru sebagai upaya untuk meningkatkan kecakapan sebagai modal dalam menghadapi kendala pada kehidupan nyata. Berikut penjelasan terkait dengan aspek life skills education.

Indikator yang digunakan untuk mengukur life skills education atau pendidikan kecakapan hidup untuk mempersiapkan dan mendukung kemampuan adaptasi guru di era revolusi industri 4.0 yaitu: (1) personal skills; (2) social skills; (3) academic skills; dan (4) vocational skills.

\section{METODE}

Metode penelitian menurut Darmawan (2014), merupakan cara yang digunakan oleh peneliti untuk mendapatkan data sekaligus informasi mengenai berbagai hal yang berkaitan dengan masalah yang akan diteliti. Dalam penelitian ini, peneliti menggunakan pendekatan kuantitatif dengan jenis rancangan penelitian deskriptif korelasional yang bersifat ex post facto.

Jumlah populasi dalam penelitian ini sebanyak 86 orang yaitu seluruh mahasiswa PTE UM angkatan 2016. Penelitian ini menggunakan teknik sampling jenuh. Ukuran sampel yang akan digunakan akan menentukan tingkat ketelitian dari penelitian yang dilakukan, tingkat kesalahan dalam penelitian ini berada pada persentase maksimal $5 \%(0,05)$. Hal ini digunakan untuk menghindari tingkat kesalahan dari total populasi yang sedikit.

Instrumen yang digunakan dalam penelitian ini berupa angket atau kuesioner tertutup. Menurut Arikunto (2010) yang dimaksud dengan kuesioner tertutup adalah kuesioner yang sudah disediakan pilihan jawabannya oleh peneliti, sehingga responden hanya memilih pilihan jawaban yang sudah tersedia. Angket atau kuesioner pada penelitian ini disusun menggunakan model skala likert.

Teknik analisis data yang digunakan adalah:(1)uji validitas instrumen;(2)uji reliabilitas instrumen; (3) uji prasyarat meliputi: uji normalitas, uji linearitas, uji autokorelasi, uji multikolinearitas, uji heterokedastisitas; dan (4) Uji Hipotesis.

\section{HASIL DAN PEMBAHASAN}

Hasil penelitian pada variabel sosial kognitif ditunjukan oleh tabel di bawah ini:

Tabel 1. Distribusi Frekuensi Variabel Adaptasi Calon Guru

\begin{tabular}{ccc}
\hline No & Kategori & Persentase (\%) \\
\hline 1 & Sangat Tinggi & 7.15 \\
2 & Tinggi & 20.20 \\
3 & Sedang & 39.30 \\
4 & Rendah & 26.20 \\
5 & Sangat rendah & 7.15 \\
\hline
\end{tabular}


Artina Tri Wistiawati, Setiadi Cahyono Putro, ahyu Sakti Gunawan Irianto. Hubungan Social Kognitif dan Life Skill Education Terhadap Kemampuan Adaptasi Calon Guru di Era Revolusi Industri 4.0

Berdasarkan pada Tabel 1 diketahui bahwa tingkat adapatasi calon guru pada mahasiswa PTE UM angkatan 2016 cenderung sedang yaitu sebesar $39.30 \%$. Berikut merupakan data sebaran tingkat sosial kognitif pada mahasiswa PTE UM angkatan 2016:

Tabel 2. Distribusi Frekuensi variabel Sosial Kognitif

\begin{tabular}{ccc}
\hline No & Kategori & Persentase (\%) \\
\hline 1 & Sangat Tinggi & 4.80 \\
2 & Tinggi & 27.40 \\
3 & Sedang & 40.50 \\
4 & Rendah & 19.00 \\
5 & Sangat rendah & 8.30 \\
\hline
\end{tabular}

Berdasarkan pada Tabel 2 diketahui bahwa tingkat sosial kognitif pada mahasiswa PTE UM angkatan 2016 cenderung sedang yaitu sebesar $40.50 \%$. Berikut merupakan data sebaran tingkat life skills education pada mahasiswa PTE UM angkatan 2016:

Tabel 3. Distribusi Frekuensi Variabel Life Skills

\begin{tabular}{ccc}
\multicolumn{3}{c}{ Education } \\
\hline No & Kategori & Persentase (\%) \\
\hline 1 & Sangat Tinggi & 3.60 \\
2 & Tinggi & 25 \\
3 & Sedang & 46.4 \\
4 & Rendah & 15.5 \\
5 & Sangat rendah & 9.5 \\
\hline
\end{tabular}

Berdasarkan pada Tabel 3 diketahui bahwa tingkat life skills education pada mahasiswa PTE UM angkatan 2016 cenderung sedang yaitu sebesar $46.4 \%$. Berikut merupakan data sebaran tingkat sosial kognitif pada mahasiswa PTE UM angkatan 2016:

Pada uji prasyarat diketahui bahwa data terdistribusi normal dengan nilai $\mathrm{P}_{\text {hit }}>\mathrm{P}_{\text {Standar }}$. Pada pengujian linearitas juga terjadi linearitas variabel dependen dengan masing-masing variabel independen. Pada pengujian multikolinearitas dan autokorelasi tidak ditemukan adanya autokorelasi maupun multikolinearitas pada data yang didapatkan melalui penelitian. Berikut merupakan hasil uji hipotesis pada penelitian ini:

Tabel 4. Hasil Uji Hipotesis Penelitan

\begin{tabular}{cccc}
\hline Hubungan & \multicolumn{2}{c}{ Probabilitas } & Interpretasi \\
\cline { 2 - 4 } Parsial & $\mathbf{P}_{\text {hitung }}$ & $\mathbf{P}_{\text {standar }}$ & \\
\hline $\mathrm{X}_{1}-\mathrm{Y}$ & 0.003 & 0.05 & $\begin{array}{l}\text { Hubungan } \\
\text { signifikan }\end{array}$ \\
$\mathrm{X}_{2}-\mathrm{Y}$ & 0.000 & 0.05 & $\begin{array}{l}\text { Hubungan } \\
\text { signifikan }\end{array}$ \\
\hline
\end{tabular}

Berdasarkan Tabel 4 diketahui bahwa $\mathrm{P}_{\text {hitung }}<\mathrm{P}_{\text {standar. }}$ Dengan demikian dapat diartikan bahwa $\mathrm{H}_{0}$ ditolak sehingga dapat disimpulkan bahwa terjadi hubungan yang signifikan secara parsial antara sosial kognitif $\left(\mathrm{X}_{1}\right)$ dengan kemampuan beradaptasi calon guru $(\mathrm{Y})$ dan terjadi hubungan parsial yang signifikan antara life skills education $\left(\mathrm{X}_{2}\right)$ dengan kemampuan beradaptasi calon guru $(\mathrm{Y})$. Berikut merupakan hasil dari pengujian hipotesis ketiga:

Tabel 5. Hasil Uji Hipotesis Ketiga

\begin{tabular}{|c|c|c|c|c|c|}
\hline \multirow{2}{*}{ Sig. F } & \multicolumn{3}{|c|}{ Coefficient } & \multirow{2}{*}{$\mathbf{R}$} & \multirow{2}{*}{$\begin{array}{c}\mathbf{R} \\
\text { square }\end{array}$} \\
\hline & Const. & $\mathbf{X}_{1}$ & $\mathbf{X}_{2}$ & & \\
\hline 0.000 & 37.28 & 0.280 & 0,428 & 0.835 & 0.6973 \\
\hline
\end{tabular}

Berdasarkan pada Tabel 5 diketahui bahwa nilai Sig.F $<0.05$ maka dapat diartikan bahwa terjadi hubungan yang signifikan secara simultan antara sosial kognitif dan life skills education dengan kemampuan berdaptasi calon guru di era revolusi industri 4.0

Masing-masing variabel memiliki sumbangan relatif (SR) dan sumbangan efektif (SE) terhadap pengaruhnya kepada variabel $Y$.

Tabel 6. Sumbangan Relatif (SR) dan Sumbangan Efektif (SE) Penelitian

\begin{tabular}{ccc}
\hline Prediktor & SE\% & SR\% \\
\hline Sosial Kognitif & $19.68 \%$ & $28.20 \%$ \\
\hline Life skills education & $59.05 \%$ & $71.80 \%$ \\
\hline Total & $69.73 \%$ & $100 \%$ \\
\hline
\end{tabular}

Berdasarkan Tabel 6 diketahui bahwa besar pengaruh variabel bebas terhadap variabel terikat sebesar $69.73 \%$ sedangkan $30.27 \%$ berasal dari faktor dan aspek lain yang tidak diteliti pada penelitian ini.

Berdasarkan hasil penelitian dapat diketahui kemampuan adaptasi calon guru di era industri 4.0 adalah sedang. Penelitian ini memaparkan bahwa kemampuan adaptasi calon guru di era revolusi industri 4.0 merupakan kemampuan mahasiswa calon guru untuk menghadapi perubahan sesuai dengan bidang tugasnya sebagai guru. Untuk menjadi calon guru yang berkompetensi dan mumpuni pada era revolusi industri 4.0 maka mahasiswa calon guru harus menyesuaikan dengan kondisi saat ini. 
Kemampuan adaptasi calon guru pada era revolusi industri 4.0 merupakan kemampuan mahasiswa calon guru untuk melakukan interaksi secara terus-menerus dengan diri sendiri ataupun orang di sekitarnya. Meinarno (2011:66) menyatakan bahwa adaptasi merupakan suatu proses penyesuaian diri terhadap lingkungan dan keadaan sekitar. Memiliki kemampuan beradaptasi digunakan untuk menyesuaikan diri dengan dinamika sekarang. Kemampuan beradaptasi yang dimaksud pada penelitian ini yaitu upaya yang dilakukan mahasiswa calon guru S1 PTE Jurusan Teknik Elektro Universitas Negeri Malang dalam menghadapi era revolusi industri 4.0 khususnya di bidang pendidikan.

Berdasarkan hasil penelitian dapat diketahui kemampuan sosial kognitif yang dimiliki oleh calon guru berada pada ketegori sedang. Sosial kognitif di dalam teori Bandura menekankan bahwa self efficacy (Efikasi diri) merupakan sebuah keyakinan terhadap penguasaan pada situasi dan kondisi tertentu. Sehingga keyakinan diri yang dimiliki oleh individu bertujuan untuk memperoleh hasil yang positif dari tindakan yang dilakukan (Santrock, 2008:286). Penelitian ini menjelaskan bahwa tingkat sosial kognitif pada calon guru merupakan upaya yang dilakukan untuk memperkuat keyakinan diri mahasiswa calon guru dalam menghadapi era revolusi industri 4.0 khususnya di bidang pendidikan.

Sosial kognitif merupakan upaya individu dalam meningkatkan keyakinan diri sebagai calon guru untuk menghadapi era revolusi industri 4.0. Meningkatkan keyakinan diri bertujuan untuk mempersiapkan individu calon guru bahwa dirinya yakin dan mampu menghadapi era revolusi industri 4.0 khususnya di bidang pendidikan. Primasari (2016:10) memaparkan bahwa dari teori Schneiders yang menjadi pengaruh terhadap penyesuaian diri adalah kematangan kepribadian, kondisi fisik, proses belajar, kondisi psikologis dan kondisi lingkungan. Sehingga sosial kognitif dibutuhkan mahasiswa calon guru untuk menghadapi emosional atau kondisi psikologis dari individu calon guru untuk dapat menyesuaikan diri pada era revolusi industri 4.0.

Berdasarkan hasil penelitian dapat diketahui bahwa life skills education yang dimiliki oleh calon guru berada pada ketegori sedang. Wulandari, dkk. (2016) mengemukakan bahwa pendidikan yang berorientasi pada kecakapan hidup menjadi sebuah alternatif pembaharuan pendidikan yang prospektif untuk mengantisipasi tuntutan masa depan. Seperti yang saat ini terjadi di masyarakat terkait upaya menghadapi perkembangan era revolusi industri 4.0 di bidang pendidikan. Pendidikan kecakapan hidup merupakan upaya untuk memperkecil perbedaan antara dunia pendidikan dengan kehidupan nyata (Noor, 2015). Hal ini juga mempunyai tujuan sebagai upaya untuk mempermudah penyesuaian diri mahasiswa calon guru dengan kehidupan di masyarakat.

\section{KESIMPULAN}

Berdasarkan hasil analisis data penelitian dan pembahasan yang telah dipaparkan dapat diperoleh kesimpulan sebagai berikut:

1. Kemampuan adaptasi calon guru pada era revolusi industri 4.0 dalam kategori sedang. Tingkat kemampuan adaptasi calon guru pada era revolusi industri 4.0 mahasiswa S1 PTE Jurusan Teknik Elektro Universitas Negeri Malang secara berturut-turut dari tertinggi ke terendah adalah pada indikator: (1)kemampuan adaptasi terhadap lingkungan sesuai dengan tugasnya; (2) kondisi diri (self personal); (3) kemampuan adaptasi terhadap perkembangan teknologi sesuai dengan tugasnya; dan (4) kemampuan adaptasi dalam melakukan pembelajaran bermakna.

2. Sosial kognitif dalam kategori sedang. Tingkat sosial kognitif mahasiswa S1 PTE Jurusan Teknik Elektro Universitas Negeri Malang secara berturut-turut dari tertinggi ke terendah adalah pada indikator: (1) mastery experience; (2) self regulation; (3) outcome expectation; (4) social persuasion; (5) vicarious learning; (6) affective states; dan (7) personal goals.

3. Life skills education dalam kategori sedang. Tingkat life skills education mahasiswa S1 PTE Jurusan Teknik Elektro Universitas Negeri Malang secara berturut-turut dari tertinggi ke terendah adalah pada indikator: (1) academic skills; (2) personal skills; (3) social skills; dan (4) vocational skills.

4. Terdapat hubungan yang positif dan signifikan antara sosial kognitif $\left(\mathrm{X}_{1}\right)$ terhadap kemampuan beradaptasi calon guru pada era revolusi industri $4.0(\mathrm{Y})$ pada mahasiswa S1 PTE Univeristas Negeri Malang.

5. Terdapat hubungan yang positif dan signifikan antara life skills education $\left(\mathrm{X}_{2}\right)$ terhadap kemampuan beradaptasi calon guru 
Artina Tri Wistiawati, Setiadi Cahyono Putro, ahyu Sakti Gunawan Irianto. Hubungan Social Kognitif dan Life Skill Education Terhadap Kemampuan Adaptasi Calon Guru di Era Revolusi Industri 4.0

pada era revolusi industri 4.0 (Y) pada mahasiswa S1 PTE Univeristas Negeri Malang.

6. Terdapat hubungan yang positif dan signifikan secara simultan antara sosial kognitif $\left(\mathrm{X}_{1}\right)$ dan life skills education $\left(\mathrm{X}_{2}\right)$ terhadap kemampuan beradaptasi calon guru di era revolusi industri 4.0 (Y) pada mahasiswa S1 PTE Universitas Negeri Malang.

\section{DAFTAR PUSTAKA}

Alessandra, T., O’Connor, M. J., Dyke, J. V. 2010. Tips Mengenal dan Menghadapi Berbagai Tipe Kepribadian. Jakarta: Indeks.

Alfaiz., Hariko, R., Zulfikar., Suarja, S. 2017. Menerbitkan Buku Bunga Rampai Kumpulan Karya Dosen Seluruh Indonesia Bidang Ilmu-ilmu Sosial dan Ilmu-ilmu Eksata. Dalam Cakti Indra Gunawan (Ed.). Perspektif Teori Kognitif Sosial dan Psikosintesis dalam Membentuk Kepribadian (hlm. 1-24). Malang: CV. IRDH (Research \& Publishing).

Amir, H. 2016. Korelasi Pengaruh Faktor Efikasi Diri dan Manajemen Diri Terhadap Motivasi Beprestasi pada Mahasiswa Pendidikan Kimia Universitas Bengkulu. Manajer Pendidikan, 10 (4), 336-142. Dari https://sc holar.google.co.id/scholar?hl=id\&as_sdt $=0 \% 2 \mathrm{C} 5 \& \mathrm{q}=$ KORELASI + PENGARU H+FAKTOR+EFIKASI+DIRI+DAN+ MANAJEMEN+DIRI+TERHADAP+M OTIVASI+BERPRESTASI+PADA+M AHASISWA+PENDIDIKAN+KIMIA+ UNVERSITAS+BENGKULU\&btnG=\# $\mathrm{d}=\mathrm{gs} \_\mathrm{qabs} \& \mathrm{u}=\% 23 \mathrm{p} \% 3 \mathrm{DEMKtTBoxlv}$ EJ.

Arikunto, S. 2010. Prosedur Penelitian Suatu Pendekatan Praktik. Jakarta: PT. Rineka Cipta.

Arikunto, S. 2015. Penelitian Tindakan Kelas. Jakarta: Bumi Aksara.

Army, D. N. R. 2017. Adaptasi Sosial Mahasiswa Ilmu Informasi dan Perpustakaan di Lingkungan Kampus-Fisip Universitas Airlangga. Skripsi tidak diterbitkan. Surabaya: FISIP Universitas Airlangga.

Arsanti, T.A. 2009. Hubungan Antara Penetapan Tujuan, Self Efficacy dan Kinerja. Jurnal Bisnis dan Ekonomi, 16(2), 97-
110. Dari https://scholar.google.co. $\mathrm{id} / \mathrm{scholar}$ ?hl=id\&as_sdt=0\%2C5\&q=H ubungan+Antara+Penetapan+Tujuan $\% 2$ $\mathrm{C}+$ Self + Efficacy + dan+Kinerja\&btnG $=$.

Astini, N.K.S. 2019. Pentingnya Literasi Teknologi Informasi dan Komunikasi bagi Guru Sekolah Dasar untuk Menyiapkan Generasi Milenial. Prosiding Seminar Nasional Dharma Acarya, 1(1), 113-120. Dari https://stahnmpuku

turan.ac.id/jurnal/index.php/dharmaacar $\mathrm{y}$ a/article/view/194.

Aziz, A. H. 2015. Peranan Kemampuan Bersosialisasi dan Beradaptasi Terhadap

Motivasi Belajar Siswa Kelas XI Jurusan Gambar Bangunan SMKN 3 Yogyakarta. Skripsi tidak diterbitkan. Yogyakarta: FT UNY.

Baharun, H. 2017. Peningkatan Kompetensi Guru Melalui Sistem Kepemimpinan Kepala Madrasah. Jurnal Ilmu Tarbiyah, 6(1), 1-26. Dari http://ejournal.sti tmuhpacitan.ac.id/index.php/tajdid/articl e/view/38. Drath, R., \& Horch, A. 2014. Industrie 4.0: Hit or Hype? [Industry Forum]. IEEE Industrial Electronics Magazine, 8 (2), 56-58. Dari https://ieeexplore.ieee. org/abstract/document/6839101.

Fajri, H.N., Johar, R., \& Ikhsan, M. 2016. Peningkatan Kemampuan Spasial dan Self Efficacy Siswa Melalui Model Discovery Learning Berbasis Multimedia. Jurnal Tadris Matematika, 9(2), 180-196. Dari https://journal. unnes.ac.id/sju/index.php/jbk/article/vie w/3752.

Feist, J., Gregory J. 2011. Teori Kepribadian. Jakarta: Salemba Muhamika.

Firman. 2019. Strategi Pendekatan Pelaksanaan Bimbingan Konseling di Sekolah Untuk Menghadapi Revolusi Industri 4.0, (Online), (10.31227/ osf.io/ud5 b7), diakses 11 Desember 2019.

Halaluddin \& Wijaya, H. 2019. Pengembangan Kompetensi Pendidikan di Perguruan Tinggi dalam Menyosong Era Revolusi Industri 4.0, (Online), (10.31219/osf.io/3mbs4), diakses 12 Desember 2019.

Hallaby, S.F., \& Hamama, S.F. 2017. Investigasi Masalah yang Dihadapi Mahasiswa Calon Guru Selama Praktik Mengajar di 
Sekolah pada Program Praktik Pengalaman Lapangan: Studi Kasus pada Mahasiswa FKIP Universitas Abulyatama. Prosiding Seminar Nasional Multi Disiplin Ilmu UNAYA, 1(1), 85-94. Dari http://jurnal.abulyatama.ac.id/index.php/ semdi unaya/article/view/192.

Hendrowati, T. Y. 2015. Pembentukan Pengetahuan Lingkaran Melalui Pembelajaran Asimilasi dan Akomodasi Teori Konstruktivitas Piaget. Jurnal eDuMath, 1 (1), 1-16. DOI https://doi.org/10.26638/je.78.2064.

Herlinda, S., Hidayat, S., \& Djumena, I. 2017. Manajemen Pelatihan Hantaran dalam Meningkatkan Kecakapan Hidup Warga Belajar di Lembaga Kursus dan Pelatihan. Journal of Nonformal Education and Community Empowerment, 1(1), 1-9. DOI https://doi.org/10.15294/pls.v1i1.14758.

Idrus, M. 2010. Metode Penelitian Ilmu Sosial. Yogyakarta: Erlangga.

Juhji., \& Rachman, M. S. 2015. Implementasi Pendidikan Kecakapan Hidup (Life Skill) Bagi Remaja Kurang Mampu. Jurnal Pengembangan Masyarakat Islam, 1 (2), 169-180. Dari http://jurnal.uinbanten.ac.id/index.php/1 brmasy/article/view/574.

Kadir, S. 2017. Konsep Life Skill Menurut Para Ahli dan Kementrian Pendidikan Nasional, (Online), (https://akarsejarah.wordpress.com/2017 /09/03/ konsep -life-skill-menurut-paraahli-dan-kementrian-pendidikannasional/), diakses 15 Desember 2019.

Kagermann, H., Lukas, W. D., \& Wahlster, W. 2011. Industrie 4.0: Mit dem Internet der Dinge auf dem Weg zur 4 Industriellen Revolution, (Online), (http://www.vdinachrichten.com/Techni k-Gesellschaft/Industrie-40Mit-Int ernet-Dinge-Weg-4-industriellenRevolution), diakses 15 Desember 2019.

Kamus Besar Bahasa Indonesia. Arti Kata Revolusi, (Online), (https://kbbi.web.id/ revolusi), diakses 15 Desember 2019.

Kamus Besar Bahasa Indonesia. Arti Kata Industri, (Online), (https://kbbi.web.id/ industri), diakses 15 Desember 2019.

Khoiri, N., Hindarto, N., \& Sulhadi. 2011. Pengembangan Perangkat Pembelajaran
Fisika Berbasis Life Skill untuk Meningkatkan Minat Kewirausahaan Siswa. Jurnal Pendidikan Fisika Indonesia, 7 (2), 84-88. DOI https://doi. org/10.15294/jpfi.v7i2.1077.

Komunikasi. 2016. Life Based Learning Mendekatkan Pembelajaran pada Kehidupan Nyata, (Online), (http://komunikasi.um.ac.id/2016/12/life -base d-learning-mendekatkanpembelajaran-pada-kehidupan-nyata/), diakses 6 Januari 2020.

Kurniawan, R. 2011. Pengaruh Self-Efficacy dan Motivasi Belajar Mahasiswa terhadap Kemandirian Belajar. Skripsi tidak diterbitkan. Yogyakarta: UNY.

Lent, R.W., Brown, S.D., \& Hacket, G. 1999. A Social Cognitive View of School-toWork Transition. The Career Development Quarterly. Special Issue: School to Work Transition. American Counseling Association, 47(1), 297-311.

Maarop, A. H., \& Embi, M. A. 2016. Implementation of Blended Learning in Higher Learning Institutions: A Review of the Literature. International Education Studies, 9 (3), 41-52. DOI 10.5539/ies.v9n3p41.

Marini, C.K., \& Hamidah, S. 2014. Pengaruh Self Efficacy, Lingkungan Keluarga, dan Lingkungan Sekolah terhadap Minat Berwirausaha Siswa SMK Jasa Boga. Jurnal Pendidikan Vokasi, 4(2), 195207. DOI https://doi.org/10.21 831/jpv.v4i2.2545.

Marwiyah, S. 2012. Konsep Pendidikan Berbasis Kecakapan Hidup. Jurnal Falasifa, 3 (1), 75-97.

Dari https://s3.amazonaws.com/academia.edu .docu ments/35383158/5-syarifatulmarwiyah-konsep-pendidikan-berbasiskeca kapan-hidup.pdf?response-contentdisposition=inline $\% 3 \mathrm{~B} \% 20$ filename $\% 3$ DSyarifatul_KONSEP_PENDIDIKAN BERBASIS_KE.pdf\&X-AmzAlg orithm=AWS4-HMAC-SHA256\&XAmz-Credential=AKIAIWOWYYG Z2Y53UL3A\%2F20200120\%2Fus-east$1 \% 2 \mathrm{Fs} 3 \% 2 \mathrm{Faws} 4$ request $\& \mathrm{X}-\mathrm{A} \quad \mathrm{mz}-$ Date $=20200120 \mathrm{~T} 073857 Z \& X-A m z-$ Expires $=3600 \& X A m z$ SignedHea ders $=$ host \&X-Amz$\underline{\text { Signature }=\mathrm{d} 1 \mathrm{f} 80 \mathrm{a} 8355 \mathrm{bd} 34 \mathrm{e} 86 \mathrm{cfd} 5902}$ 
Artina Tri Wistiawati, Setiadi Cahyono Putro, ahyu Sakti Gunawan Irianto. Hubungan Social Kognitif dan Life Skill Education Terhadap Kemampuan Adaptasi Calon Guru di Era Revolusi Industri 4.0

b55ebf370b24

9d83974ada4370f9cf0f83125953.

Meinarno, E. A. 2011. Manusia Dalam Kebudayaan Masyarakat. Jakarta: Salemba Humanika.

Minarti, E.D., \& Nurfauziah, P. 2016. Pendekatan Konstruktivitisme dengan Model Pembelajaran Generatif Guna Meningkatkan Kemampuan Komunikasi dan Koneksi Matematis serta Self Efficacy Mahasiswa Calon Guru di Kota Cimahi. Jurnal Ilmiah UPT P2M STKIP Siliwangi, 3(2), 68-83. Dari http:// www.e-

journal.stkipsiliwangi.ac.id/index.php/p $2 \mathrm{~m} /$ article/view/629.

Mufanti, R. 2015. Penumbuhan Soft Skill Siswa dalam Proses Pembelajaran. (Online), (http://seminar.umpo.ac.id/index.php/se mnasdik 2015/article/ viewFile/222/223), diakses 15 Desember 2019.

Mujahada, K. S. 2019. Memperkuat Eksistensi Pendidikan Islam dalam Menghadapi Era Revolusi Industri 4.0. Jurnal Pendidikan dan Agama Islam, 2 (2), 38-48. DOI https://doi.org/10.87868/saliha.v2i2.33.

Mukhadis, A. 2016. Metode Penelitian Kuantitatif. Malang: Aditya Media Publishing.

Neolaka, A. 2016. Metode Penelitian dan Statistik. Bandung: PT. Remaja Rosdakarya.

Ni'mah, A., Tadjri, I., \& Kurniawan, K. 2014. Hubungan antara Dukungan Sosial dan Self Efficacy dalam Menyelesaikan Skripsi. Indonesian Journal of Guidance and Conseling, 3(1), 43-48. Dari https://journal.unnes.ac.id/sju/in dex .php/jbk/article/view/3752.

Noor, A.H. 2015. Pendidikan Kecakapan Hidup (Life Skill) di Pondok Pesantren dalam Meningkatkan Kemandirian Santri. Jurnal Empowerment, 3 (1), 1-31. DOI https://doi.org/10.22460/empowerment. v4i1p1-31.553.

Nur, A. 2013. Peranan Pendekatan Academic Skill dalam Pembelajaran Terhadap Hasil Belajar Fisika Siswa SMA Negeri 9 Makassar. Jurnal Pendidikan Fisika, 1 (1), 1-7. DOI https://doi.org/10.26618/jpf.v1i1.1 $\underline{83}$.

Nuryadi A., \& Ginting, A.A. 2017. Self Control dan Self Efficacy Mempengaruhi
Prokrastinasi Akademik pada Mahasiswa. Jurnal Ilmiah Adiraga, 3(2), 34-42.

Dari https://scholar.google.co.id/scholar?hl=i d\&as $\mathrm{sdt}=0 \% 2 \mathrm{C} 5 \& \mathrm{q}=\mathrm{Se}$

lf+Control+dan+Self+Efficacy+Mempe ngaruhi+Prokrastinasi+Akademik+pada + Mahasiswa\&btnG $=$.

Prasetyo, H., \& Sutopo, W. 2018. Industri 4.0: Telaah Klasifikasi Aspek dan Arah Perkembangan Riset. J@ti Undip: Jurnal Teknik Industri, 13 (1), 17-26. DOI https://doi.org/10.14710/jati.13.1.17-26.

Primasari, R. 2016. Pengaruh Self-Efficacy toward Ajustment on Dormitory Students of Andalas University. Skripsi tidak diterbitkan. Padang: FK Universitas Andalas.

Priyatno, D. 2014. SPSS 22 Pengolah Data Terpraktis. Yogyakarta: Andi.

Putro, S.C. 2017. Muatan Social Cognitive untuk Memfasilitasi Pengembangan Kemampuan Adaptasi Calon Guru pada Kurikulum Prodi S1 PTE di LPTK. Disertasi tidak diterbitkan. Malang: UM.

Putro, S. C., Elmunsyah, H., Putranto, H., \& Nidhom, A. M. 2017. Pengaruh Aspek Sosial Psikologis Terhadap Kesiapan Menjadi Guru SMK di Jurusan TE FT UM. Jurnal Teknologi, Kejuruan, dan Pengajarannya, 40 (1), 59-68. DOI http://dx.doi.org/10.17977/um031v40i1 $2017 \mathrm{p} 059$.

Risdianto, E. 2019. Analisis Pendidikan Indonesia di Era Revolusi Industri 4.0, (Online), (https://www.researchgate.net/publicatio $\mathrm{n} / 332423142 \quad$ ANALISI S PENDIDIKAN INDONESIA DI E RA REVOLUSI INDUSTRI 40), diakses 15 Desember 2019.

Rosada, M. A. 2018. Hubungan Self Regulatory Learning, Personal Goal Setting, dan Persepsi terhadap Profesi Guru dengan Literasi menjadi Guru Kejuruan Teknologi pada Mahasiswa S1 PTE UM. Skripsi tidak diterbitkan. Malang: FT UM.

Ruliyanti, B.D., \& Laksmiwati, H. 2014. Hubungan Antara Self-Efficacy dan Self-Regulated Learning dengan Prestasi Akademik Matematika Siswa SMAN 2 Bangkalan. Jurnal Penelitian Psikologi, 3(2), 1-7. Dari https://jurnalmah 
asiswa.unesa.ac.id/index.php/character/a rticle/view/10976.

Sabna E., \& Muhardi. 2016. Penerapan Data Mining untuk Memprediksi Prestasi Akademik Mahasiswa Berdasarkan Dosen, Motivasi, Kedisiplinan, Ekonomi, dan Hasil Belajar. Jurnal CoreIT, 2(2), 41-44. DOI http://dx.doi.o $\mathrm{rg} / 10.24014 /$ coreit.v2i2.2392.

Santia, I. 2016. Peningkatan Soft Skill Mahasiswa Calon Guru Matematika Melalui Critical Lesson Study. Jurnal Pedagogia, 5 (2), 157-168. DOI https://doi. Org/10.21070/pedagogia.v5i2.247.

Santoso, S. 2012. Panduan Lengkap SPSS Versi 20. Jakarta: PT. Elex Media Komputindo.

Santrock, J. W. 2008. Psikologi Pendidikan. Terjemahan Tri Wibowo. Jakarta: Kencana.

Salundung, J. 2010. Pengembangan dan Penerapan Logic Model pada Program Pembelajaran Penguatan Vocational Life Skills Berbasis Wirausaha. Jurnal Kependidikan, 40 (2), 137-156. DOI https://doi.org/10.21831/jk.v40i2.494.

Smith, S.M. 2002. Using the Social Cognitive Model to Explain Vocational Interest in Information Technology. Information Technology, Learning, and Performance Jurnal, (Online), 20(1), 1-8. Dari semanticscholar.org/paper/ Using-theSocial-Cognitive-Model-To-Explain-inSmith/a7f44f42da2511e 57081881049cfa375da43e08f.

Sobari, T. 2012.Penerapan Teknik Siklus Belajar dalam Pembelajaran Menulis Laporan Ilmiah Berbasis Vokasional di SMK. Jurnal Ilmiah Program Studi Pendidikan Bahasa dan Sastra Indonesia, 1(1), 1741. DOI https://doi.org/ 10.22460/semantik.v1i1.p\%25p.

Soyomukti, N. 2010. Pengantar Sosiologi. Yogyakarta: Ar-Ruzz Media.

Sudijono, A. 2014. Pengantar Statistik Pendidikan. Jakarta: Raja Grafindo Persada.

Sugiyono. 2011. Metode Penelitian Kuantitatif, Kualitatif, dan R\&D. Bandung: Alfabeta. Sugiyono. 2017. Metode Penelitian Kuantitatif, Kualitatif, dan $R \& D$. Bandung: Alfabeta.

Sugiyono. 2018. Metode Penelitian Kuantitatif, Kualitatif, dan $R \& D$. Bandung: Alfabeta.
Sujarweni, W. 2014. Metodologi Penelitian: Lengkap, Praktis dan Mudah Dipahami. Yogyakarta: PT. Pustaka Baru.

Sujarweni, W. 2015. SPSS untuk Penelitian. Yogyakarta: PT. Pustaka Baru.

Tarsidi, D. 2010. Teori Social Cognitive Albert Bandura, (Online), (http://file.upi .edu/Direktori/FIP/JUR. PEND. LUAR BIASA/195106011979031-DIDI

TARSIDI/Makalah\%26Artikel_Tarsidi PLB/TEORI KOGNITIF SOSIAL.pd f), diakses 20 Maret 2020 .

Tung, K. Y. 2015. Pembelajaran dan Perkembangan Belajar. Jakarta: Indeks.

Turley, S., Powers, K., \& Nakai, K. 2006. Beginning Teachers Confidence Before and After Induction. Journal Action in Teacher Education, 28, 27-39. DOI https://doi.org/10.1080/01626620.2006. 10463565 .

UURI No. 20 tahun 2003 tentang Sistem Pendidikan Nasional, UURI No. 14 tahun 2005 tentang Guru dan Dosen, PP No. 19 tahun 2005 tentang Standar Nasional Pendidikan. Bandung: Fermana.

Wanto, A. 2011. Model Pendidikan Kecakapan Hidup (Life Skills) Bagi Remaja Panti Asuhan Al Hikmah Wonosari Ngaliyan Semarang. Skripsi tidak diterbitkan. Semarang: Fakultas Tarbiyah IAIN Walisongo.

Wijaya, I. P., \& Pratitis, N. T. 2012. Efikasi diri akademik, dukungan sosial orang tua dan penyesuaian diri mahasiswa dalam perkuliahan. Jurnal Persona, 1 (1), 4052.

DOI https://doi.org/10.30996/persona.v1i1.1 4.

Winata, A. 2014. Adaptasi Sosial Mahasiswa Rantau dalam Mencapai Prestasi Akademik. Skripsi tidak diterbitkan. Bengkulu: FISIP Universitas Bengkulu.

Wulan, N. S. 2012. Hubungan antara Social Cognitive dan Penguasaan Keterampian dengan Kesiapan Memasuki Dunia Kerja bagi Siswa pada Kompetensi Keahlian TKJ SMK di Kota Malang. Skripsi tidak diterbitkan. Malang: FT Universitas Negeri Malang.

Wulandari, V., Koryati, D., \& Fitriyanti. 2016. Pelaksanaan Pendidikan Life Skills dalam Program Wirausaha Siswa Kelas XI SMA Negeri 5 Palembang. Jurnal Profit Kajian Pendidikan Ekonomi dan 
Artina Tri Wistiawati, Setiadi Cahyono Putro, ahyu Sakti Gunawan Irianto. Hubungan Social Kognitif dan Life Skill Education Terhadap Kemampuan Adaptasi Calon Guru di Era Revolusi Industri 4.0

Ilmu Ekonomi, 3 (2), 175-182. Dari https://ejournal.unsri.ac.id/index.php/jp/ article/view/5569.

Yalina, N., \& Rozas, I. N. 2018. Manajemen Layanan Teknologi Informasi:

Tantangan dalam Kurikulum Perguruan Tinggi di Era Revolusi Industri 4.0. Seminar Nasional Riset Terapan, 3, 5869. Dari http://eprosiding.poliban. ac.id/index.php/snrt/article/view/272.

Zhang, A. 2012. Peer Assessment of Softskills and Hard Skills. Journal of Information Technology Education: Research, 11(1),
155-168.
Dari
https://

www.learntechlib.org/p/111498/. 